\section{Stemming the Tanning Bed Epidemic: Time for Action}

\author{
Alan C. Geller, MPH, RN; Sophie J. Balk, MD; and David E. Fisher, MD, PhD
}

Tanning bed use, particularly among teenaged girls and young women, has become increasingly commonplace in the United States, often exceeding smoking in these populations. ${ }^{1-4}$ Contrary to misconceptions that tanning beds are only used for special occasions, more than $40 \%$ of those who use tanning beds do so more than 10 times per year. ${ }^{2-4}$ Furthermore, the past 2 years have been marked by well-respected studies with large sample sizes strongly linking tanning beds to melanoma and other skin cancers. ${ }^{1,5,6}$ Fueled by the proliferation of tanning salons in the United States, which now seem to outnumber Starbucks or McDonalds, and a very low per-use cost, nearly $40 \%$ of girls aged 16 and 17 years have used tanning beds in the past year, and more than 1 million people tan in tanning salons each day in the United States.

In response, coordinated efforts led by skin cancer patient advocates and physicians have resulted in restrictions in many states and a first-time ban in the United States on the use of tanning beds for children younger than 18 years in California and Vermont. Many other parts of the world now ban tanning beds for youth, and Brazil and part of Australia (New South Wales) have population-wide bans. We are now in the incipient stage of a public health campaign akin to the one that reduced smoking in teens, and the parallel components are striking. Advocates work to enact statewide legislation, public health experts and industry testify at FDA hearings, media attention has heightened, and federal tax policies to disincentivize use have been instituted.

\section{Indoor Tanning Rise and Melanoma Risk}

Like smoking rates that grew precipitously in the relatively short period between World Wars, the use of artificial tanning has dramatically risen since the tanning industry emerged in the 1980s, accounting for at least 19,000 free-standing salons and more than $\$ 5$ billion in annual sales. Touting tanning beds' ability to raise vitamin $\mathrm{D}$ levels is but one claim used by the tanning industry to encourage use. Others include statements that people who use tanning beds are less likely to sunburn; that burningnot tanning-at an early age increases skin cancer later in life; that tanned skin is protective; that a tan is protective during vacation; and, finally, that tanning in children is an issue of parents' rights and government should not interfere. At state hearings, the tanning industry often claims that physician referrals for medical phototherapy constitute a significant minority of tanning bed visits.

Earliest studies examining melanoma risk associated with indoor tanning used small sample sizes and short intervals between exposure and disease; these often showed equivocal results. Later studies, conducted between 1995 and 2005, were included as part of the International Agency of Research on Cancer (IARC) landmark finding in 2006 that artificial exposure to ultraviolet (UV) light was carcinogenic.

Since then, new studies have strengthened the association between tanning bed use and increased melanoma risk and have documented that risk. ${ }^{7}$ The Australian Melanoma Family Study, a population-based case-control family study of early-onset melanoma, examined 604 patients diagnosed between ages 18 and 39 years and 479 control subjects. The association was stronger for melanoma diagnosed at 18 to 29 years of age (odds ratio [OR] for $>10$ lifetime sessions, 6.57; 95\% CI, 1.41-30.49) than for melanoma diagnosed at 30 to 39 years $(\mathrm{OR}, 1.60 ; 95 \% \mathrm{CI}, 0.92-2.77 ; \mathrm{P}=.01$

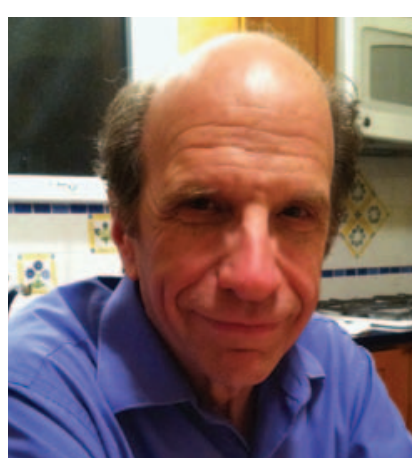

Alan Geller, MPH, RN

Alan Geller, MPH, RN, is currently a Senior Lecturer in the Department of Society, Human Development, and Health at the Harvard School of Public Health as well as the Director of Melanoma Epidemiology at Massachusetts General Hospital, Department of Dermatology. His research includes work in tanning bed policy and legislation, melanoma epidemiology, and early detection, screening, and education for reducing melanoma mortality. $\mathrm{He}$ is a former Co-Chair of the National Council on Skin Cancer Prevention.

The ideas and viewpoints expressed in this editorial are those of the author and do not necessarily represent any policy, position, or program of NCCN. 


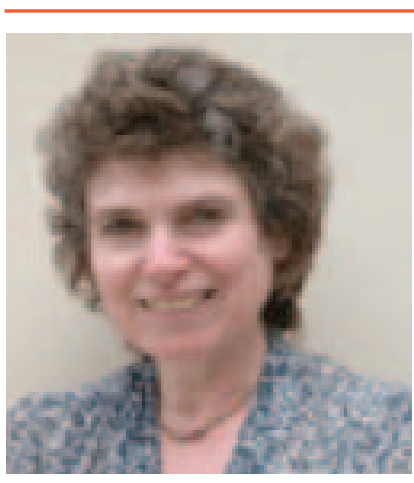

Sophie J. Balk, MD

Sophie J. Balk, MD, is a general pediatrician at the Children's Hospital at Montefiore and Professor of Clinical Pediatrics at the Albert Einstein College of Medicine in Bronx, New York. She received her undergraduate degree from Cornell University and her MD from the Albert Einstein College of Medicine. She practices pediatrics and teaches residents and students in a community-based health center in Bronx, New York. Dr. Balk's academic work focuses on environmental health issues relevant to children. She was Chairperson of the American Academy of Pediatrics (AAP) Committee on Environmental Health from 1999 to 2003. She is Associate Editor of the 3 editions of Pediatric Environmental Health, a manual for clinicians published by the AAP; the 3rd edition was published in 2012. She has written and lectured on environmental health issues relevant to clinical practice, including pediatric tobacco issues and skin cancer prevention. She was the lead author of the "AAP Technical Report and Policy Statement on Ultraviolet Radiation" published in 2011. for interaction). Among those who had ever used a tanning bed and were diagnosed between 18 and 29 years of age, $76 \%$ of melanomas were attributable to tanning use. ${ }^{5}$ A large Minnesota study involving 1167 patients with melanoma and 1101 control subjects ages 25 to 59 showed that $63 \%$ of patients and $51 \%$ of controls had ever tanned indoors (adjusted OR, 1.74; 95\% CI, 1.42-2.14). Greater risk was associated with greater use when examined with regard to years of exposure $(P<.006)$, hours $(P<.0001)$, or sessions $(P=.0002)$. Odds ratios were elevated within each initiation age category; years of use among indoor tanners was more relevant for melanoma development. ${ }^{1}$

Tanning bed use is both a risky behavior and all too common practice. According to data from the 2009 Youth Risk Behavior Survey, a nationally representative sample of high school students in grades 9 through 12, more than one-quarter of all teen girls reported using a tanning device in the past 12 months. A critical age for the uptake of tanning bed use begins in adolescence. The rate of artificial tanning among white girls increases with age, more than doubling from 14 to $15(7 \%-15 \%)$ and doubling again at age $17(35 \%) .^{3}$ By the age of 18 to 21 years, $32 \%$ of young women use tanning beds, at an average of 28 sessions per year. ${ }^{8}$ Rates are high in all young white populations, including childhood cancer survivors who are now in their early 30 s. Of that populations, at least $30 \%$ report ever using tanning beds.

\section{Tanning and Addiction}

Molecular studies have helped to explain the pathways involved in UV-induced skin pigmentation, and have also suggested potential mechanistic explanations for the possibility of addictive consequences. On UV exposure, epidermal keratinocytes undergo DNA damage, which triggers the stabilization and consequent upregulation of the p53 tumor suppressor protein. Among p53's transcriptional targets, the prohormone pro-opiomelanocortin $(\mathrm{POMC})$ is actively expressed and processed, resulting in keratinocyte secretion of the POMC-derived cleavage peptide, melanocytestimulating hormone $(\mathrm{MSH})$. Subsequent activation of the MSH receptor on melanocytes (the melanocortin 1 receptor) results in a cAMP upregulation of the master transcriptional regulator of pigment genes (MITF) and subsequent production of melanin within melanosome vesicles. The vesicles are eventually trafficked out to keratinocytes, in which most epidermal melanin resides.

Molecular analyses also indicated that another POMC derived peptide, $\beta$-endorphin, is simultaneously synthesized in skin after UV irradiation, suggesting the possibility that $\beta$-endorphin's role as an endogenous opiate might contribute to an opiate-like behavioral response to UV irradiation. Although direct evidence for such a pathway has not been presented to date, several studies have yielded observations consistent with this possibility, including a study suggesting that frequent indoor tanners could discern UV-emitted versus sham UV sources after blinded exposures. Researchers have also observed that administration of the opiate receptor antagonist naltrexone to frequent indoor tanners elicited withdrawal-like symptoms. Although additional molecular study will likely shed more mechanistic detail on the pathways connecting UV to addiction, these observations strongly support the concept of an organic basis. ${ }^{9-12}$

\section{Tanning and Public Health Legislation}

Legislative campaigns, still in their infancy, have produced 3 major victories in the past year. In October 2011, California became the first state in the United States to ban salon tanning for minors younger than 18 years. Vermont followed in May 
2012. The City Council of Chicago, Illinois, banned under-18 salon tanning in June 2012, and 32 states have adopted some type of restriction by age or included parental consent and accommodation language.

Several nations have banned salon tanning for teenagers. However, no federal legislation has been passed in the United States to restrict minors from salon tanning. Pressing for reclassification of tanning beds and a ban on teen use, more than 40 experts, and melanoma survivors with prior tanning bed use, testified before the FDA in March 2010 on the health risks associated with indoor tanning. However, at the time of writing, 27 months later and after a needless number of tanning-bed-related skin cancers, the FDA has yet to act.

\section{Conclusions and Future Research}

Much clinical, epidemiologic, and behavioral research is needed. For example, studies are needed to confirm and measure the true extent of tanning bed addiction. Second, little is known about why some people stop using tanning beds and how these "dropouts" differ from those who continue use. Third, more research, possibly involving political scientists, can help advocates learn how to build a critical mass supporting a federal ban on salon tanning for teenagers. Finally, although statewide and federal bans are vital, understanding how to enforce these bans requires even greater attention.

Oncologists, family physicians, pediatricians, internists, dermatologists, and allied health professionals can inquire and actively counsel teen and young adult patients to refrain from using tanning beds. In addition, because parents often have a powerful influence on their children, physicians who treat children and adolescents can involve parents in the discussions. Individual physicians and physician organizations have historically played significant roles in public health campaigns, such as those to pass legislation requiring seat belts and banning text messaging while driving, to encourage stronger nutritional standards, and to reduce youth access to tobacco products and alcohol. Physicians armed with research findings or personal accounts of patients whom they have counseled to discourage tanning bed use can play more powerful roles than the lobbyists for the tanning bed industry and proprietors of tanning salon businesses, who often populate local, state, and federal hearings. In fact, in the past few years, the WHO, American Academy of Pediatrics, American Academy of Dermatology, American Medical Association, Society of Surgical Oncology, and other organizations have strongly recommended legislation to ban children younger than 18 years from indoor tanning, ${ }^{13}$ and constituents have testified at state legislative hearings.

\section{References}

1. Lazovich D, Vogel RI, Berwick M, et al. Indoor tanning and risk of melanoma: a case-control study in a highly exposed population. Cancer Epidemiol Biomarkers Prev 2010;19:1557-1568.

2. Guy GP, Tai E, Richardson LC. Use of indoor tanning devices by high school students in the United States, 2009. Prev Chronic Dis 2011;8:A116.

3. Geller AC, Colditz G, Oliveria $S$, et al. Use of sunscreen, sunburning rates, and tanning bed use among more than 10,000 US children and adolescents. Pediatrics 2002;109:1009-1014.

4. Cokkinides V, Weinstock M, Lazovich D, et al. Indoor tanning use among adolescents in the US, 1998 to 2004. Cancer 2009;115:190-198.

5. Cust AE, Armstrong BK, Goumas C, et al. Sunbed use during adolescence and early adulthood is associated with increased risk of early-onset melanoma. Int J Cancer 2011;128:2425-2435.

6. Veierød MB, Adami H, Lund E, et al. Sun and solarium exposure and melanoma risk: effects of age, pigmentary characteristics, and nevi. Cancer Epidemiol Biomarkers Prev 2010;19;111-120.

7. The International Agency for Research on Cancer Working Group on Artificial Ultraviolet (UV) 
Geller et al

Light and Skin Cancer. The association of use of sunbeds with cutaneous malignant melanoma and other skin cancers: a systematic review. Int J Cancer 2007;120:1116-1122.

8. Centers for Disease Control and Prevention. Use of indoor tanning devices by adults—United States, 2010. MMWR Morb Mortal Wkly Rep 2012;61:323-326.

9. Feldman SR, Liguori A, Kucenic M, et al. Ultraviolet exposure is a reinforcing stimulus in frequent indoor tanners. J Am Acad Dermatol 2004;51:45-51.

10. Fisher DE, James WD. Indoor tanning: science, behavior, and policy. N Engl J Med 2010;363:901903.

11. Harrington $\mathrm{CR}$, Beswick TC, Leitenberger J, et al. Addictive-like behaviours to ultraviolet light among frequent indoor tanners. Clin Exper Dermatol 2010;36:33-38.

12. Kourosh AS, Harrington CR, Adinoff B. Tanning as a behavioral addiction. Am J Drug Alcohol Abuse 2010;36:284-290.

13. Balk SJ; American Academy of Pediatrics, Committee on Environmental Health and Section on Dermatology. Technical report: ultraviolet radiation—a hazard to children and adolescents. Pediatrics 2011;127:e791-817.

Statement of Circulation:

1. Publication Title: JNCCN—Journal of the National Comprehensive Cancer Network. 2. Publication Number: 1540-1405. 3. Filing Date: 8/30/12. 4. Issue Frequency: Monthly. 5. Number of Issues Published Annually: 12. 6. Annual Subscription Price: Individual Print \$520; Institutional Print \$830. 7. Complete Mailing Address of Known Office of Publication: Harborside Press, LLC, 37 Main St, Cold Spring Harbor, Suffolk, NY 11724-1423. 8. Complete Mailing Address of Headquarters or General Business Office of Publisher: Harborside Press, LLC, 37 Main St, Cold Spring Harbor, Suffolk, NY 11724-1423. 9. Full Names and Complete Mailing Addresses of Publisher, Editor, and Managing Editor: Publisher - John A. Gentile Jr, Harborside Press, LLC, 37 Main St, Cold Spring Harbor, Suffolk, NY 11724-1423.; Editor - Harold J. Burstein MD, PhD, National Comprehensive Cancer Network, 275 Commerce Dr, Ste 300, Fort Washington, PA 19034; Managing Editor - Kimberly A. Callan, MS, ELS, National Comprehensive Cancer Network, 275 Commerce Dr, Ste 300, Fort Washington, PA 19034. 10. Owner: Full Name - Harborside Press, LLC; John A. Gentile, Jr. (Principal), Anthony Cutrone (Principal), Conor Lynch (Principal). Complete Mailing Address: 37 Main St, Cold Spring Harbor, Suffolk, NY 11724-1423. 11. Known Bondholders, Mortgagees, and Other Security Holders Owning or Holding 1 Percent or More of Total Amount of Bonds, Mortgages or Other Securities: None.. 13. Publication Title: JNCCN-Journal of the National Comprehensive Cancer Network. 14. Issue Date for Circulation Data Below: September 2012. 15. Extent and Nature of Circulation. Average No Copies Each Issue During Preceding 12 Months: a) Total Number of Copies 24,451. b) Legitimate Paid and/or Requested Distribtuion (By Mail and Outside the Mail) (1) Outside County Paid/Requested Mail Subscriptions stated on PS Form 3541 12,714. c) Total Paid and/or Requested Circulation 12,714. d) Nonrequested Distribtuion (By Mail and Outside the Mail) (1) 11,326. (4) Nonrequested Copies Distributed Outside the Mail 155. e) Total Nonrequested Distribtuion 11,481. f) Total Distribution 24,195. g) Copies not Distributed 256. h) Total 24,451. i) Percent Paid and/or Requested Circulation 52\%. 15. Extent and Nature of Circulation. No Copies of Single Issue Published Nearest to Filing Date: a) Total Number of Copies 24,071. b) Legitimate Paid and/or Requested Distribtuion (By Mail and Outside the Mail) (1) Outside County Paid/ Requested Mail Subscriptions stated on PS Form 3541 12,271. c) Total Paid and/or Requested Circulation 12,271. d) Nonrequested Distribtuion (By Mail and Outside the Mail) (1) 11,800. e) Total Nonrequested Distribtuion 11,800. f) Total Distribution 24,071. g) Copies not Distributed 256. h) Total 24,327. i) Percent Paid and/or Requested Circulation 51\%. 16. Publication of Statement of Ownership for a Requester Publication is required and will be printed in the October 2012 issue of this publication. 17. Signature of Publisher: John A. Gentile. Date 8/30/12. 